Ненад Станојевић ${ }^{1}$

Наталија Јовановић ${ }^{2}$

Универзитет у Нишу, Филозофски факултет
Оригинални научни рад

UDK 316.74:373.3(=214.58)(497.11 Ниш)

Примљено: 11.9.2019.

Ревидирана верзија: 23.1.2020.

Одобрено за штампу: 24.1.2020.

DOI: https://doi.org/10.46630/gsoc.25.2020.03

\title{
СОЦИЈАЛНА ЕКСКЛУЗИЈА РОМСКИХ УЧЕНИКА У ОСНОВНИМ ШКОЛАМА У НИШУ
}

\begin{abstract}
Ancтракт: Указујући да је социјална ексклузија један од кључних разлога ниског образовног постигнућа, аутори анализирају социјалну ексклузију ромских ученика у основним школама у Нишу. Рад се састоји из три дела: најпре се износе подаци који показују друштвени и образовни статус ромске популације, затим се приказују најзначајнији нормативни оквири инклузије Рома, а на крају се приказују резултати истраживања о социјалној ексклузији ромских ученика у основним школама у Нишу. Закључује се да ромски ученици нису интегрисани у вршњачке групе и да постоји изражена социјална дистанца према њима.
\end{abstract}

Кључне речи: ромски ученици, образовање, социјална ексклузија, инклузија

\section{Увод}

Од успостављања међународног протектората над Косовом, Роми представљају уз Мађаре најбројнију националну мањину ${ }^{4}$ у Србији. Према званичним подацима Пописа из 2011. године у Србији (без Косова) има их 147 604, што је око $2 \%$ од укупног броја становника. Статистичка евиденција о Ромима је непоуздана због њихових честих миграција, непријављивања места становања, социјалне мимикрије (која је често резултат дискриминације, предрасуда, стереотипа и одбацивања од већинског становништва) и непостојања докумената, па се сматра да је њихов број већи него што истраживања показују. Бројне процене ромских организација и цивилног сектора указују да их има три пута више, тачније око 450000.

\footnotetext{
${ }^{1}$ nenad.stanojevic@filfak.ni.ac.rs

${ }^{2}$ natalija.jovanovic@filfak.ni.ac.rs

${ }^{3}$ Рад је настао у оквиру интерног пројекта Корак ка професионализацији сощиологије 2: анализа потреба за професијом, који реализује Департман за социологију Филозофског факултета у Нишу уз подршку Министарства просвете, науке и технолошког развоја Републике Србије.

${ }^{4}$ „Наравно, мањине у друштвеном смислу нису просто мањине по броју припадника групе, већ по томе што су припадници тих група због неких својих одлика маргинализовани, дискриминисани, издвојени од других и од већине, што немају сва права која имају припадници већине, па, наравно, постају свесни, понекад болно, таквог свог положаја“ (Žunić 2005: 8).
} 
Роми су једна од најугроженијих и најнепривилегованијих друштвених група. Они су најмногољуднији народ који живи у дијаспори, без сопствене државе матице, који свуда доживљава друштвену, економску, политичку и културну маргинализацију. По својим обичајима, традицији, језику, религији и начину живота се разликују од већинског становништва; те разлике доприносе мултикултурализму земље, али представљају и изворе неразумевања. Често су присутне нетрпељивост и дискриминација Рома, управо због њиховог начина живота.

Анализа њиховог социоекономског положаја може најбоље показати са којим тешкоћама се сусрећу: сиромаштво, масовна незапосленост, недовољно образовање, неприступачност друштвеним институцијама итд. О положају Рома се може доста закључити и на основу занимања, која одређују висину зараде, па самим тим и економски и социјални статус.

„У време свог боравка у јужнословенским земљама, између XII и XIX века, Роми су били чергари, дежурни сезонски гости на вашарима и пијацама, путујући артисти, седеће градске занатлије, трговци, али и обесправљено робље, у Влашкој и Молдавији. Живели су углавном у посебним џематима, у градским чаршијама и већим сеоским насељима или на утринама поред њих““ (Тодоровић 2011: 1146).

Роми су раније обављали оне послове који су се сматрали недостојним припадника владајућег слоја, те су били музиканти, певачи, играчи, забављачи итд. Већина њихових занимања је праћена ниским накнадама и друштвеним неуважавањем.

„Битна одлика поменутих и других друштвених улога Рома је да нису захтевале нарочито школовање, већ је била довољна практична обука унутар уобичајених подела између чланова породица, каравана, черге или неког другог начина њиховог удруживања и социјалног живота“ (Милосављевић 2009: 108).

Резултати Пописа становништва из 2011. године показују да су они најчешће чистачи, помоћни радници, скупљачи секундарних сировина $(59,3 \%)$, возачи и занатлије $(10,8 \%)$, пољопривредни и сродни радници $(9,9 \%)$, продавци $(8,9 \%)$, грађевински радници $(6,9 \%)$, ноћни чувари и конобари $(2,6 \%)$ и уметници (1,5\%) (Радовановић и Кнежевић 2014: 79). Треба подсетити да су занимања којима се баве директна последица лоше образовне структуре.

Чини се да се Роми налазе у ,зачараном кругу” сиромаштва, незапослености и лошег образовања (А. Митровић). Схватајући да је образовање основни канал друштвене мобилности у данашњем друштву и кључ за промену положаја и социјалну инклузију, држава је предузела одређене кораке који би требало да побољшају стање у овој области. Неки од најважнијих тичу се социјалне инклузије у основним школама. Поред систематичног и организованог развијања интересовања и способности за ваљано обављање професионалних улога, улога школе је и да на младе пренесе владајући вредносни систем и подучи их адекватним понашањима за живот у социјалној заједници. На тај начин би школа могла да допринесе развијању духа толеранције и интеркулту- 
ралног друштва. У следећем делу ћемо приказати податке о образовању Рома, који ће нам делимично осликати њихов друштвени положај.

\section{Проблеми у образовању Рома}

Обухваћеност системом државног образовања у Србији најнижа је међу припадницима ромске националне мањине. Најнижи проценти уписа у основну школу, завршавања разреда и преласка на средњошколско образовање односе се на ромску децу. Последица тога је значајно гора образовна структура Рома у поређењу са остатком популације, што представља велику препреку за побољшање њиховог друштвеног положаја.

Подаци из последња два пописна периода откривају нам образовни профил Рома.

Табела 1. Удео неписмених Рома по полу према попису из 2002. и 2011. године:

\begin{tabular}{|c|c|c|c|}
\hline \multirow{2}{*}{} & \multicolumn{3}{|c|}{ Удео неписмених Рома старијих од 10 година по полу: } \\
\cline { 2 - 4 } & укупно & мушко & женско \\
\hline 2002. & $19,6 \%$ & $11,8 \%$ & $27,6 \%$ \\
\hline 2011. & $15,1 \%$ & $9,2 \%$ & $21,2 \%$ \\
\hline
\end{tabular}

Иако се из табеле 1 може уочити смањење удела неписмених у ромској популацији у периоду између два пописа за око 4\%, Роми увелико надмашују национални просек (2\%). Може се уочити и изражена разлика у нивоима писмености мушкараца и жена: Ромкиње су више од два пута неписменије од Рома.

Табела 2. Школска спрема становништва Србије и Рома према попису из 2011. године:

\begin{tabular}{|c|c|c|c|c|c|}
\hline \multicolumn{5}{|c|}{ Школска спрема за укупно становништво и Роме према попису из 2011. године: } \\
\hline & $\begin{array}{c}\text { Без } \\
\text { школске } \\
\text { спреме }\end{array}$ & $\begin{array}{c}\text { Непотпуно } \\
\text { основно } \\
\text { образовање }\end{array}$ & $\begin{array}{c}\text { Основно } \\
\text { образовање }\end{array}$ & $\begin{array}{c}\text { Средње } \\
\text { образовање }\end{array}$ & $\begin{array}{c}\text { Више и } \\
\text { високо } \\
\text { образовање }\end{array}$ \\
\hline Роми & $20 \%$ & $34,2 \%$ & $33,3 \%$ & $11,5 \%$ & $0,7 \%$ \\
\hline $\begin{array}{c}\text { Укупно } \\
\text { становништво }\end{array}$ & $2,7 \%$ & $11 \%$ & $20,7 \%$ & $48,9 \%$ & $16,2 \%$ \\
\hline
\end{tabular}

И на нивоу школске спреме могу се уочити значајне разлике између ромске популације и осталог становништва. Преко трећине Рома $(34,2 \%$ у односу на $10,9 \%$ опште популације) нема завршену основну школу, трећина Рома има основно образовање, а тек $11,5 \%$ има средње, насупрот готово половине укупног 
становништва у нашој земљи. Ситуација је још алармантнија када је у питању више и високо образовање: свега 0,7\% припадника ромског етноса може се подичити дипломом високе школе или факултета (наспрам 16,2\% опште популације).

Значајан извор података о положају ромске деце у образовању је извештај Образовна инклузија деце ромске националности (Jovanović 2013), који су публиковали УНЕСКО и Центар за образовне политике. У спроведеном мониторингу у основношколском образовању узорак је чинило осам школа са 536 ромских ученика од првог до петог разреда. У наведеном извештају посебно се истичу индикатори инклузивности у образовању ромских ученика: школски успех, изостајање из школе, осипање и додатна образовна подршка.

Када је реч о школском успеху, подаци из школских дневника говоре да ромски ученици постижу нижи школски успех у односу на просечан одељењски успех. Према прикупљеним подацима, ромски ученици до петог разреда имају просечну оцену за једну нижу од просечне оцене одељења, да би у петом разреду та разлика износила 1,5 оцене заостатка. Указује се и на константан заостатак ромских ученика током школовања из српског језика и математике, посебно се истиче забринутост због ниског постигнућа ромских ученика из математике на крају петог разреда (просечна оцена је мања од довољног успеха, износи 1,9).

Друга група података обухвата изостанке (оправдане и неоправдане) ромских ученика који су узимани из дневника на крају разреда, па су упоређивани са изостанцима неромских ученика. Подаци показују да ромски ученици имају много виши степен изостанака од неромских, у просеку ромски ученик годишње начини (узимајући у обзир ученике од првог до петог разреда) 43,2 оправдана изостанка више од неромских ученика. У случају неоправданих часова ретка је пракса да се дају у млађим разредима, али се њихов број драматично увећава међу ромским ученицима који похађају пети разред: просечно их је 69.58 по ученику. Такође, занимљив је податак да је у овом истраживању скоро сваки десети ромски ученик прекинуо школовање: на узорку од 536 њих 48 је прекинуло школовање (8,9\%).

Запитајмо се који су то фактори који доводе до овако лоше образовне структуре ромског становништва и потражимо начине на који би се овакво стање поправило. Требало би обратити пажњу најпре на две области: средине из којих децуа долазе и иколска средина.

Најпре треба указати на нестимулативну средину из које ромска деца долазе. За Роме, који су свој живот подредили пуком преживљавању, школовање њихове деце нема значајну вредност. Проблем представља културни капитал који ромска деца усвајају у породици. Бурдије указује да образовање репродукује обрасце класних и других друштвених неједнакости, односно, институције образовања врше легитимизацију друштвених неједнакости. Културни капитал се уграђује у друштвени положај појединаца и група - припадност средњим и вишим класама даје предност у образовном систему, јер се у образовању репродукује доминантна култура (Burdije i Paseron 2014). Не треба 
занемарити ни језичку баријеру. Језик представља систем комуникације, али га не треба сводити само на то, јер се „сматра једним од најважнијих средстава за иницирање, синтетизовање и подстицање мишљења, осећања и понашања - функционално повезаних са групом“ (Bernštajn 1979: 22). Језик обезбеђује мање или више богат вокабулар и систем сложених категорија чија употреба зависи од сложености језика усвојеног унутар породице.

Дакле, ромска деца се тешко уклапају у школски систем због непознавања језика, услова у којима живе и неадекватног културног капитала, лошег материјалног положаја породице због којег су често принуђени да веома рано морају да напусте школу да би радили итд.

Са друге стране, у школи се ромска деца суочавају са непријатностима од стране неромске деце, родитеља и наставника због предрасуда, стереотипа, дискриминације и постојеће социјалне дистанце према њима (Миладиновић 2008; Frančesko, Mihić i Kajon 2005; Тодоровић 2007; Đorđević, Todorović and Milošević 2004). Истраживања показују изразито неприхватање и постојање бројних негативних стереотипа према ромској популацији. Резултати истраживања Миладиновића (2008) показују да су они на дну прихваћености од стране већинских Срба. Од тринаест посматраних етничких група Роми заузимају ниско једанаесто место, испод њих се на скали налазе само Муслимани/Бошњаци и Албанци. Док се негативан однос према овим групама може објаснити сукобима који су постојали у прошлости или који и данас постоје, са Ромима није било сукоба па се овакав однос према њима може објаснити бројним предрасудама и стереотипима који постоје. Аутор указује да су њихово генерацијско сиромаштво и начин живота оно што узрокује овакав однос према њима. Франческо, Михић и Кајон долазе до занимљивих резултата да чак и код деце основних школа (узраста 11-12 година) постоји значајна социјална дистанца, као и постојање негативних стереотипа према Ромима. Социјална дистанца према Ромима износи 2,36 (од максималних 4). Иза њих се налазе Мађари са дистанцом 1,02 и Хрвати са дистанцом од 0,96. Интересантни су подаци о социјалној дистанци самих ромских ученика. Очекивано, укупна социјална дистанца је мања него код неромске деце, али је чак и код ромске деце највећа социјална дистанца према Ромима и износи 1,60 (Frančesko, Mihić i Kajon 2005: 172). Резултати овог истраживања показује да стереотипи других према Ромима садрже и позитивне и негативне особине, док аутостереотипи ромске деце садрже углавном позитивне особине.

Ови подаци нам показују неравноправан образовни и друштвени положај Рома. Реч је, дакле, о есклузији ромских ученика. У наставку рада ћемо се детаљније позабавити овим проблемом.

\section{Ексклузија ромских ученика}

Истраживања показују да социјална изолованост и вршњачка неприхваћеност значајно корелирају са ниским образовним постигнућем (Krnjajić 2002: 167). Социјална искљученост у бројним друштвеним аспектима доводи 
и до искључености у образовном систему. То се неповољно одражава на успех ромске деце у школи, што касније доводи до продубљивања проблема ове маргинализоване друштвене групе.

За боље разумевање појма социјалне ексклузије мора се поменути и појам социјалне инклузије. Ово су два супротна појма која описују стање различитих маргинализованих појединаца/група, односно мере које би требало предузети за њихово укључивање у друштво. Ексклузија је последица кидања веза између појединаца и друштва и испољава се у појавама беде, сиромаштва, дискриминације, маргинализације и сл. Резултат социјалне ексклузије је да су појединци или групе спречени да у потпуности учествују у економском, политичком и друштвеном животу друштва у којем живе (Mimica i Bogdanović 2007: 116). Као одговор на различите облике социјалне ексклузије, држава разрађује и примењује различите облике социјалне инклузије (односно реинтеграције појединаца/група у друштво). Социјална инклузија подразумева низ мера које морају бити предузете да би појединци могли да учествују у друштвеном, политичком, економском и културном животу. Конкретно, у школи треба да омогући да деца из маргиналних група (у овом случају Роми) постану интегрални део и да учествују у активностима (наставним и ваннаставним) са осталим ученицима. Примена инклузивног модела у школи претпоставка је развијања већег степена толерантности и међусобног разумевања. То би довело до веће кооперације ученика и могло би повољно да се одрази на постигнуће ромске деце. Укључивањем у активности школе деца задовољавају потребу да буду заједно са вршњацима, што доводи до прихваћености, припадности и сигурности. Према томе, „вршњачка интеракција обезбеђује деци могућност да практикују своје социјалне вештине и на тај начин унапређује и убрзава социјално-когнитивни развој деце. Зато, да би остварило социјално и когнитивно напредовање, дете мора да буде у контакту са другим особама, укључујући и вршњаке“ (Krnjajić 2002: 33). Развој когнитивних способности зависи и од интеракције са другим особама.

Проблем у образовању ромских ученика представљају и очекивања наставника, која се могу дефинисати као „закључци које наставници доносе о будућем понашању или школском постигнућу својих ученика, а заснивају ce на информацијама које наставници поседују о својим ученицима“" (Good \& Brophy 1991, према: Krnjajić 2002: 125). Као и у неким другим ситуацијама, очекивања наставника су често условљена стереотипима, предрасудама и социјалном дистанцом. На тај начин и наставници производе разлике међу ученицима. Школски успех ученика није искључиво последица његових стварних интелектуалних способности и залагања, већ зависи и од наставниковог понашања, односно његовог уверења да је дете способно за учење и да ће остварити добар успех или, пак, да је ниских способности и да ће имати тешкоћа у учењу (Suntherland \& Goldschmid 1974). Крњајић посебно истиче значај студије Pygmalion in the classroms Розендала и Јакобсона (Rosendathal \& Jacobson 1968). У овом истраживању су аутори манипулисали наставниковим очекивањима ученичког постигнућа. 
„Експеримент је обављен у једној државној школи, у социјално и етнички мешовитој области у близини Сан Франциска. У истраживање су била укључена по три одељења из сваког од првих шест разреда. Након администрирања теста општих способности, наставницима је саопштено да се у њиховим одељењима налази један број ученика (око 20\%) од којих се може очекивати изузетан интелектуални напредак током неколико наредних месеци. Ова психолошка прогноза била је измишљена, односно лажна. Ученици су, у ствари, били изабрани случајно, а не на основу тест-скорова, тако да нису постојали реални разлози да се од њих очекује неки значајнији успех у учењу. Па ипак, на крају школске године, испоставило се да се ова измишљена прогноза остварила...” (Krnjajić 2002: 123)

Очекивања која су изазвана давањем лажних информација су подстакла наставнике да различито третирају ученике - то је довело до њиховог остваривања високих резултата. Оваква очекивања наставника се повезују и са ученицима разних етничких група. У мешовитим срединама наставници су склони да верују да припадници одређених етничких група брже и више уче од припадника других етничких група (Clifton 1981).

У српским школама се од ромских ученика мало очекује, па им се мало пружа. Социјална искљученост ромске деце доводи до бројних последица. Утиче на смањење усвајања когнитивних знања и социјалних вештина и додатно продубљује проблеме ромске националне мањине.

\section{Нормативни оквир инклузије}

Држава, препознавши тежак положај ромске популације, доноси бројне законе и стратегије којима настоји да створи предуслове за социјалну инклузију Рома. Када говоримо о законима, стратегијама и акционим плановима у Србији, морамо поћи од основног и највишег правног акта у Републици Србији који уређује рад државних органа и права грађана, а то је Устав (Устав Републике Србије 2006) који је усвојен 30. септембра 2006. године. Он је основ за развијање политике заштите националних мањина и њиме се уређује њихов положај - у њему се истичу пуна равноправност и уважавање идентитета свих националних мањина. Уставом се указује да Република Србија штити права националних мањина и да јемчи посебну заштиту националним мањинама ради остваривања потпуне равноправности и очувања њиховог идентитета (члан 14). Такође, отвара се простор за увођење афирмативних мера, у члану 21 се каже да се дискриминацијом не сматрају посебне мере „које Република Србија може увести ради постизања пуне равноправности лица или групе лица која су суштински у неједнаком положају са осталим грађанима“.

Узимајући у обзир тежак положај Рома и проблеме са којима се сусрећу, треба истакнути значај Закона о заштити права и слобода националних манина (2009). Он је основни закон који уређује статус националних мањина. Основна начела на којима се заснива систем заштите мањина су: забрана дискриминације, мере за обезбеђивање равноправности, слобода националног опредељи- 
вања и изражавања, сарадња са сународницима у земљи и иностранству итд. Закон предвиђа, када је реч о Ромима, и увођење посебних мера за постизање једнакости па се у оквиру мера за обезбеђивање равноправности каже да ће „органи власти [he] донети правне акте и предузети мере из става 1 овог члана у циљу поправљања положаја лица која припадају ромској националној мањини“ (члан 4). Према овом закону, националне мањине имају право на национално опредељење, употребу матерњег језика, на слободно исповедање религије, на употребу националних симбола, право на неговање културе и традиције итд. У овом контексту треба поменути и Закон о забрани дискриминащије (2009). Овим законом се уређују општа забрана дискриминације, облици и случајеви дискриминације као и поступци заштите од дискриминације.

Када се анализирају закони који су битни за Роме, као једне од највећих националних мањина у Србији, а имајући у виду њихов социоекономски положај, нужно је представити и Закон о сощијалној заштити (2011). Ово је важно због чињенице да велики број припадника ромске популације живи од социјалне помоћи. ${ }^{5}$ Социјална заштита је скуп мера и активности које држава, односно одговарајуће институције, предузимају да би се пружила помоћ појединцима којима је она потребна. Она има два основна облика:

1) Материјална помоћ - новчана социјална помоћ, додатак за помоћ и негу другог лица, увећани додатак за помоћ и негу другог лица, помоћ за оспособљавање за рад и једнократна помоћ;

2) Услуге социјалне заштите-услуге процене и планирања, дневне услуге у заједници, услуге подршке за самосталан живот, саветодавнотерапијске и социјално-едукативне услуге, услуге смештаја и услуге неодложних интервенција.

Социјална заштита, у смислу овог закона, јесте организована друштвена делатност од јавног интереса чији је циљ пружање помоћи и оснаживање за самосталан и продуктиван живот у друштву појединаца и породица, као и спречавање настајања и отклањање последица социјалне искључености. Новчана социјална помоћ је један од најчешћих начина помоћи припадницима ромске националне мањине, али се може поставити питање у којој мери је делотворна. Поред новчаних помоћи, неопходно је указивати на значај образовања, као кључног чиниоца који може довести до промене положаја и помагати у овој области да би се омогућила независност ромске популације од институција социјалне заштите. ${ }^{6}$ Зато је веома важно анализирати и законе из области образовања.

Најважнији закон из ове области је Закон о основама система образоваға и васпитања (2009), јер кроз њега афирмативе мере добијају пуну институцио-

\footnotetext{
${ }^{5}$ „Више од једне четвртине (27,6\%) од укупно ромских домаћинстава своје приходе је остваривало преко социјалних примања, што потврђује да се Роми налазе на крајњем ступњу друштвене лествице“ (Радовановић и Кнежевић 2014: 94).

${ }^{6}$ Један од основних задатака социјалног рада је и оснаживање корисника које би требало да омогући појединцима/групама да преузму контролу над властитим животом.
} 
нализацију у законском оквиру. Овим законом се уређују основе предшколског, основног и средњег образовања и васпитања. У њему се, између осталог, говори о принципима, циљевима и стандардима образовања и васпитања. Овим законом се указује да сви грађани Републике Србије имају једнако право на образовање и васпитање, без обзира на пол, расу, националну, верску и језичку припадност, социјално и културно порекло, имовно стање, узраст, физичку и психичку конституцију, сметње у развоју и инвалидитет, политичко опредељење или другу личну особину (члан 6). На основу овог закона је формиран низ подзаконских аката (правилника) који описују обавезе и одговорности различитих актера и начине спровођења инклузивног образовања. За подручје нашег интересовања можемо указати на значај увођења припремног предиколског програма (ППП), афирмативних акичја приликом уписа, индивидуалних образовних планова и педагошких асистената.

Закон о основама система образовања и васпитања, најсвеобухватнији закон из области образовања, отклонио је неке од слабости образовног система, као нпр. чињеницу да су пре доношења овог закона деца из различитих група могла бити упућена у специјалне школе без пристанка њихових родитеља. Један од најзначајнијих доприноса овог закона су смернице за инклузивно образовање, чији је циљ да се промени образовна пракса. Законом су уведене одредбе које промовишу једнака права, приступ и квалитетно образовање за све.

Један од битних корака који су предузети да се унапреди образовни положај и пружи додатна образовна подршка ромским ученицима је увођење педагошких асистената. У Закону о основама система образовања и васпитања се прописује да педагошки асистент пружа помоћ и додатну подршку деци и ученицима, у складу са њиховим потребама и помоћ наставницима, васпитачима и стручним сарадницима у циљу унапређивања њиховог рада са децом и ученицима којима је потребна додатна образовна подршка (члан 117). Педагошки асистенти су уведени у образовни систем како би помогли ромским ученицима да се уклопе у образовни систем, у савладавању језичких баријера итд.

Правилник о програму обуке педагошких асистената (2009) предвиђа да се у радни однос на место педагошког асистента ангажује особа која има завршену средњу школу и познаје ромски језик. Такође, предвиђено је да ангажовани треба да прођу обуку за обављање ових послова. У члану 4 се указује да се педагошки асистенти обуком оспособљавају за обављање послова који се посебно односе на: континуирано унапређивање рада са децом и ученицима којима је потребна додатна подршка у образовању и васпитању, пружање помоћи васпитачу, наставнику и стручном сараднику, сарадњу и рад са родитељима и породицом, успостављање сарадње и процедура.

Иако је увођење педагошких асистената позитиван корак, који ће омогућити инклузију у образовни систем и боље образовно постигнуће ромских ученика, може се поставити питање да ли предвиђене послове треба да обавља један човек (средњошколског образовања) или већину ових послова треба да раде неки други стручњаци у школи (Коматина 2016: 199). Такође, у пракси се положај педагошких асистената показао као проблематичан. Они имају статус 
спољног сарадника без могућности да радни однос на одређено време (12 месеци) прерасте у радни однос на неодређено време. Процедуре за ангажовање педагошког асистента нису довољно правно уређене, нити транспарентне, а послови које обављају често се разликују од установе до установе.

„Недовољно законски конкретизован делокруг рада отвара могућност да сваки појединачни асистент различито тумачи и практикује улогу асистента и да свака предшколска и основношколска установа, такође различито, разуме њихову улогу и дефинише очекивања од педагошког асистента. Зато актуелни опис посла варира од једног до другог асистента, од једне до друге предшколске установе или основне школе [..] Један део асистената обавља посао учитеља/наставника или преузима посао стручних служби. Друга група асистената истиче да има школа које педагошке асистенте не користе у настави, већ их користе као спољне сараднике на терену или као испомоћ за обављање свих административно-техничких послова које одреди директор установе или неко од наставног или васпитачког кадра" (Milivojević 2015: 19-20).

На крају, треба поменути и Стратегију за соичјално укључивање Рома и Ромкиња у Републици Србији за период од 2016. до 2025. године (2016). Како се наводи у Стратегији, иако су у протеклом периоду постигнути одређени резултати у вези са трајним унапређењем положаја Рома и Ромкиња, главне препреке за социјално-економску интеграцију Рома и Ромкиња нису отклоњене. Општи циљ Стратегије је побољшање социјално-економског положаја ромске националне мањине у Србији, уз пуно уживање мањинских права, елиминисање дискриминације и веће социјалне укључености у све сегменте друштва.

Поред ових представљених закона, треба поменути још неке законе, пре свега из области образовања, који су значајни за ову тему: Закон о уцбеницима и другим наставним средствима, Закон о предшколском васпитаюу и образовању, Закон о основном образовању и васпитању, Закон о средюем образовању и васпитању; као и стратегије: Стратегија за смањење сиромаштва, Стратегија за унапређивање положаја Рома у Републищи Србији, Стратегија развоја образовања у Србији до 2020. године.

Доношење ових закона показује вољу за решавање проблема и покушаје побољшања стања и друштвене инклузије Рома. Стварање адекватне правне основе је неопходно да би се створили услови за социјалну инклузију Рома. „Међутим, како се домен нормативног и реалног никада не преклапају, попут слике и њеног одраза у огледалу, потребно је истражити колика су та одступања. Подаци из различитих области друштвеног живота су најбољи индикатори и мера те диспропорције“ (Реtrović 2016: 50). У следећем делу ћемо приказати податке о социјалној ексклузији Ромских ученика у основним школама у Нишу, који ће нам показати у којој мери су ови закони делотворни. 


\section{Ексклузија ромских ученика у основним школама у Нишу}

У наставку рада представићемо резултате истраживања ${ }^{7}$ спроведеног 2017. године у двема нишким основним школама: ОШ „Краљ Петар I“ и ОШ „Радоје Домановић“. Истраживање се састојало из два дела, први део истраживања се односи на ученике који су попуњавали анкете, а други део на податке који су прикупљени уз помоћ стручних сарадника о наставним и ваннаставним активностима. Анкета је садржала индикаторе социјалне ексклузије и скалу социјалне дистанце. За мерење социјалне дистанце коришћена је модификована Богардусова скала коју су користили Франческо, Михић и Кајон испитујући ученике основних школа у Новом Саду (2005). Реч је о скали која је конструисана уз помоћ педагога, психолога и професора разредне наставе тих школа тако да буде разумљива ученицима основних школа, само је у скали коју смо користили у овом истраживању понуђен још један однос (да ти буде момак/ девојка), јер је за разлику од поменутог истраживања ово спроведено међу ученицима виших разреда у основним школама. Дакле, у скали је понуђено пет типова односа: да живи у твојој улици, да иде у твоју школу, да седи са тобом у клупи, да буде твој другар и да ти буде момак/девојка. Од етничких група поред Рома били су понуђени и Срби, Словенци, Хрвати, Бошњаци/Муслимани, Црногорци, Македонци и Албанци. За сваку од ових етничких група ученици су процењивали прихватљивост за ова пет понуђена односа.

Прва школа у којој је вршено истраживање, „Краљ Петар I“, имала је укупно 1014 ученика, од чега 123 ученика ромске националности (око 12\%). Број ромских ученика који је редовно похађао наставу је 92 (према подацима школе чак 27 ромских ученика се налазило у иностранству). Истраживање је спроведено међу ученицима од 5. до 8. разреда. Овде се уочава осипање ромских ученика, што је поготово уочљиво у завршним разредима (7. и 8. разред). У истраживању, у којем је изабрано по једно одељење од 5. до 8. разреда", учествовало је укупно 89 ученика. Друга школа у којој је, „Радоје Домановић“, имала је укупно 732 ученика, од чега 174 ромска ученика (око 23\%), али, као и у првој школи, имала је мањи број редовних ромских ученика - 140. И овде се наводи да је велики број ученика у иностранству. Када анализирамо број ромских ученика од 5. до 8. разреда, и у овој школи се може уочити осипање ромских ученика, поготово у завршном разреду. Као и у претходној школи и овде је изабрано по једно одељење од 5. до 8. разреда, а учествовало је укупно 52 ученика. Према томе, у истраживању је учествовао укупно 141 ученик, од чега је било 16 ромских ученика $(11,3 \%)^{9}$.

Основни циљ истраживања је дескрипција социјалне ексклузије ром-

\footnotetext{
${ }^{7}$ Позивамо се на истраживање реализовано током израде нашег мастер рада, одбрањеног на Филозофском факултету у Нишу 16. 10. 2017. године (Станојевић 2017).

${ }^{8}$ Избор одељења је био случајан, помоћу програма Random number generator.

9 Један од проблема који се јавио током истраживања је добијање сагласности родитеља за учествовање у истраживању.
} 
ских ученика у основним школа у Нишу, као и утврђивање области у којима би требало интервенисати како би се омогућила боља социјална инклузија у школама, што ће дугорочно обезбедити и инклузију у друштво и побољшање положаја ове друштвене групе. Основне претпоставке од којих се пошло су: да ромска деца нису интегрисана у школску заједницу, да постоји изражена социјална дистанца према ромској деци и да ромска деца знатно мање учествују у ваннаставним активностима од неромске деце.

Резултати истраживања показују да ромски ученици нису интегрисани у групу вршњака. Више од половине неромских ученика (56\%) нема искуство седења у клупи са ромским учеником. Скоро две трећине ученика (64\%) никада није позвало на рођендан ромског ученика, а више од две трећине ученика никада није учило са ромским учеником. Више од половине неромских ученика не сматра да би требало да уче више о ромској култури, традицији и историји. Разлог за такав став условљен је стереотипима и предрасудама које постоје према ромској култури. Социјална дистанца према ромским ученицима на скали од 0 до 5 износи 2,61. Од фактора који утичу на дистанцу издвојен је свакодневни контакт са Ромима, јер је уочена разлика између оних који немају свакодневни контакт са Ромима (дистанца износи 2,98) и оних који имају (дистанца износи 2,18). Код ромских ученика може се уочити тежња ка прихватању од стране неромских ученика. Такође, њихови одговори показују да се радо друже са неромским ученицима (75\%), да се играју са неромским ученицима (преко $85 \%$ ) и да проводе слободно време са неромским ученицима (преко 50\%).

Ваннаставне активности су усмерене на продубљивање веза између ученика, па и према већем прихватању неромских ученика. Учесталост дружења, причања и игре са ромским ученицима је добар начин да се превазиђу баријере између ромских и неромских ученика. Када је у питању слободно време, оно које не проводе у школи, када ученици имају слободу избора, 83,2\% неромских ученика никад или ретко проводи слободно време са ромским ученицима и овакав однос према ромским ученицима од стране неромских је изражен у обема школама. Социјална дистанца према Ромима између ученика ових школа је потпуно иста. Када је реч о социјалној дистанци према Ромима, може се уочити да што је ближи/интимнији однос понуђен, то постоји већи степен неприхватања. Око две трећине неромских ученика прихвата да Роми иду у њихову школу и да им буду другови, а око половине испитаника би прихватило да Роми живе у њиховој улици. Међутим, велики број испитаника не би прихватио да седи са Ромима у клупи или да им они буду момак/девојка.

Ромски ученици нису у потпуности интегрисани у групу вршњака - већина неромских ученика је одговорила да никад нису седели у клупи са ромским учеником, да никада нису позвали на рођендан ромског ученика и да никада нису учили са ромским учеником. Дистанца која је присутна између ромских и неромских ученика резултат је неприхватања друге стране и неукључивања у школске и друге социјалне активности. Упознавање, стална комуникација у истом, школском, простору, заједничке, школске активности и ваншколске нису довеле до потпуног прихватања двеју страна. Упознавање и познавање друге 
етничке групе јесте пожељан услов за превазилажење искључености, али није и довољан услов за интеграцију и инклузију ромских ученика у школски систем и у вршњачку групу. При анализи школских тимова и секција за ученике, уочено је да постоје напори школе за што већим укључивањем ромских ученика у ваннаставне активности. Ово је значајан ресурс који би могао да буде коришћен у превазилажењу дистанце и баријера између ромских и неромских ученика. Школске активности, како наставне тако и ваннаставне, могу се искористити у функцији афирмације прихватања различитости и развоја интеркултуралности. Оне би требало да омогуће боље упознавање и прихватање других и другачијих и развију већи степен међусобног разумевања (Todorović 2019). На овај начин би се деци из маргиналних и сиромашних група омогућило веће укључивање у школске активности и припремање за интеграцију и инклузију у друштво.

\section{Закључак}

Роми су национална мањина у Србији са највећим ризиком од сиромаштва и социјалног искључења. Један од главних узрока оваквог положаја је лоша образовна структура ромске популације, неукључивање ромских ученика у образовни систем, одустајање од школовања, ниске образовне аспирације, лош успех, одустајање од образовања на вишим нивоима и сл. Ромски ученици су у основним школама изложени лошој интеграцији у вршњачку групу, дистанцама, стереотипима, дискриминацији и сегрегацији. Сусрећу се са бројним проблемима у школској средини што утиче на њихов однос према вршњацима неромима и школским обавезама. Законска регулатива у смислу позитивне дискриминације ромских ученика није довољна за разумевање и прихватање од стране окружења; постоји раскорак између правног и реалног положаја ових ученика, који су често маргинализовани и изоловани од стране неромских ученика и наставника. Речју, незадовољавајућа је друштвена укљученост ове маргинализоване групе у школску средину и недовољна интегрисаност у групе вршњака што се несумњиво одражава и на каснији положај ромске популације у друштву.

Школске активности, како наставне тако и ваннаставне, требало би да буду у функцији афирмације културе мира и развоја интеркултуралности. Оне би требало да омогуће боље упознавање себе, али и упознавање других. Такође би требало да доведу до развијања вишег степена толеранције и међусобног разумевања. На тај начин би се деци из маргиналних и сиромашних група омогућило веће укључивање у школске активности и припремање за касније активније друштвено укључивање. Неопходно је разумети да проблем није само у ромској заједници, већ и у односу друштва према њима. Поред школских активности, морала би да постоји и сарадња и координација активности невладиних организација и локалне власти. 


\section{Литература}

Bernštajn, B. (1979) Jezik i društvene klase. Beograd: BIGZ.

Burdije, P. i Paseron, Ž. K. (2014) Reprodukcija: elementi za jednu teoriju obrazovnog sistema. Beograd: Fabrika knjiga.

Đorđević, D. B., D. Todorović, and L. Milošević. (2004) Romas and Others - Others and Romas (Social Distance). Sofia: Institute for Social Values and Structures „Ivan Hadjiyski“"

Закон о забрани дискриминације (2009), Службени гласник РС бр. 22/2009.

Закон о заштити права и слобода националних мањина (2009), Службени гласник РС бр. 72/2009 - др. закон и 97/2013- одлука УС.

Закон о основама система образовања и васпитања (2009), Службени гласник РС бр. 72/2009, 52/2011, 55/2013, 35/2015-аутентично тумачење, 68/2015 и 62/2016одлука УС

Закон о социјалној заштити (2011), Службени гласник РС бр. 24/2011.

Jovanović, V. (ur). (2013) Obrazovna inkluzija dece romske nacionalnosti. Beograd, Centar za obrazovne politike.

Коматина, С. (2016) Актуелни проблеми образовања Рома у Србији: друштвени изазови и одговори (докторска дисертација). Ниш: Филозофски факултет.

Krnjajić, S. (2002) Socijalni odnosi i obrazovanje. Beograd: Institut za pedagoška istraživanja.

Миладиновић, С. (2008) „Етничка и социјална дистанца према Ромима”, Социолошки преглед XLII (3): 417-437.

Milivojević, Z. (2015) Analiza pravnog okvira i aktuelnog statusa i prakse pedagoških asistenata, Tim za socijalno uključivanje i smanjenje siromaštva i Vlada Republike Srbije.

Милосављевић, М. (2009) „(Не)могућности социјалне укључености Рома”, Социјална мисао 2/2009: 101-121.

Mimica, A. i Bogdanović, M. (2007). Sociološki rečnik. Beograd: Zavod za udžbenike.

Petrović, J. (2016) Životi u senci: sociološka studija o osobama sa invaliditetom u Srbiji. Ниш: Универзитет у Нишу.

Правилник о програму обуке педагошких асистената (2009), Службени гласник РС бр. $72 / 09$.

Радовановић, С. и Кнежевић, А. (2014) Попис становништва, домаћинстава и станова 2011. у Републици Србији: Роми у Србији. Београд: Републички завод за статистику.

Тодоровић, Д. (2007) Друштвена удаљеност од Рома (Етничко-религијски оквир). Ниш и Нови Сад: Филозофски факултет у Нишу и Stylos.

Тодоровић, Д. (2011) „Роми на Балкану и у Србији”, Теме 35(4): 1137-1174.

Todorović, D. (2019) „Tolerance, Multiculturalism and Interculturalism in the Balkans”, Facta Universitatis: series Philosophy, Sociology, Psychology and History 17, 1 (2019): 30-44. 
Станојевић, Н. (2017) Социјална инклузија ромске деце у основним школама у Нишу (мастер рад). Ниш: Филозофски факултет.

Стратегију за социјално укључивање Рома и Ромкиња у Републици Србији за период од 2016. до 2025. године (2016), Службени гласник РС бр. 26/2016.

Suntheral, A. \& Goldschmid, M. (1974) „Negative teacher expectation and IQ change in children with superior intellectual potential", Children Development, vol.45, no 3,: 852-856. DOI: $10.2307 / 1127861$

Устав Републике Србије (2006), Службени гласник РС бр. 98 /2006.

Frančesko, M., Mihić, V. i Kajon, J. (2005) „Socijalna distanca i stereotipi o Romima kod dece novosadskih osnovnih škola", Psihologija 39 (2): 167-182.

Clifton, R. (1981) ,Ethnicity, techers' expectationsand the academic achievment process in Canada", Sociology of education, vol 54, no 4: 291-301. DOI: 10.2307/2112570

Žunić, D. (ur). (2005) Prava manjina. Niš: Odbor za građansku inicijativu.

Nenad Stanojević

Natalija Jovanović

\section{SOCIAL EXCLUSION OF ROMA STUDENTS IN PRIMARY SCHOOLS IN NIŠ}

Abstract: Indicating that social exclusion is one of the key reasons for low academic achievement, the authors analise social exclusion of Roma students in primary schools in Niš. The paper constists of three parts: the data of social and educational status of Roma population are presented first, then the most important laws of Roma inclusion, and finally, the results of research of Roma student's social exclusion in elementary schools in Niš are depicted. The conclusion is that Roma students are not integrated into their peer groups and that there is a noticeable social distance towards them.

Keywords: Roma students, education, social exclusion, inclusion 